University of Nebraska - Lincoln DigitalCommons@University of Nebraska - Lincoln

2013

\title{
From Mounds to Maps to Models: Visualizing Ancient Architecture Across Landscapes
}

Heather Richards-Rissetto

University of Nebraska-Lincoln, richards-rissetto@unl.edu

Follow this and additional works at: http:// digitalcommons.unl.edu/anthropologyfacpub

Part of the Archaeological Anthropology Commons, Digital Humanities Commons, Geographic Information Sciences Commons, Landscape Architecture Commons, Latin American Languages and Societies Commons, and the Urban Studies and Planning Commons

Richards-Rissetto, Heather, "From Mounds to Maps to Models: Visualizing Ancient Architecture Across Landscapes" (2013).

Anthropology Faculty Publications. 64.

http://digitalcommons.unl.edu/anthropologyfacpub/64

This Article is brought to you for free and open access by the Anthropology, Department of at DigitalCommons@University of Nebraska - Lincoln. It has been accepted for inclusion in Anthropology Faculty Publications by an authorized administrator of DigitalCommons@University of Nebraska Lincoln. 


\title{
From Mounds to Maps to Models
}

\author{
Visualizing Ancient Architecture across Landscapes
}

\author{
Department of Geography \\ Middlebury College \\ Middlebury, VT (USA) \\ hrichardsrissetto@middlebury.edu
}

Heather Richards-Rissetto

\author{
Department of Anthropology \\ University of New Mexico \\ Albuquerque, NM (USA) \\ h.m.richards.rissetto@gmail.com
}

\begin{abstract}
Since the onset of settlement pattern studies in the 1950s, landscape mapping projects have become an archaeological mainstay. Remote sensing technologies such as lidar, photogrammetry, and SAR (Synthetic Aperture Radar) steadily reveal new archaeological sites. For landscape archaeology, the detection and mapping of small architectural complexes and households offers important data to contextualize larger (often already known) sites and perform regional analyses. However, because the majority of sites remain unexcavated, analysis is limited, and yet Geographic Information Systems (GIS) and 3D Visualization are expanding the possible uses for older and newly-acquired data on unexcavated mounds. This paper describes a GIS approach to interpolate architectural data from maps of unexcavated mounds into 3D models useful for landscape archaeology. The case study is the ancient Maya city of Copan-today a UNESCO World Heritage Site in Honduras.
\end{abstract}

Keywords - 3D Visualization, GIS, Landscape Archaeology, Maya Archaeology, Visibility Analysis

\section{INTRODUCTION}

Until the mid-twentieth century, most archaeology focused on monumental architecture. While this top-down perspective stems from historical interests, it is also simply because such sites are both more recognizable and well-known. Beginning in the 1950s with the onset of settlement pattern studies [1], mapping projects across large areas began to capture not only large temples or palaces but also smaller structures. A bottomup perspective took hold with increasing interest in everyday life [2]. Landscape archaeology stems from such work, but bridges top-down and bottom-up approaches by studying the ways that past peoples across the social spectrum constructed, shaped, and made use of their environment.

Remotely sensed data such as lidar, SAR (Synthetic Aperture Radar) and satellite and photogrammetric imagery, which permit the detection and mapping of small architectural complexes and households $[3,4]$, are transforming archaeology. Rapid acquisition of large datasets, particularly in impenetrable terrain, allows archaeologists to increasingly contextualize larger (often already known) sites and perform regional analyses. While such newly-acquired data are important, older data acquired from pedestrian surveys still remain invaluable as they often include (1) data on now destroyed or eroded sites and (2) archaeological analysis on surface finds (e.g., associated artifacts) that aerial surveys cannot collect.
This paper describes a GIS approach to interpolate data from maps of unexcavated mounds to generate 3D architectural models across archaeological landscapes. Because 3D models store data in structures that reference locations in 3D space (in contrast to $2.5 \mathrm{D}$ data (surfaces) where $\mathrm{z}$-values are stored as an attribute), they permit advanced architectural visualization and analysis, for example, of building interiors. However, a key concern, particularly in dealing with unexcavated mounds, is realism vs. reality, and raises the question: Are such models useful for research or simply for teaching and public outreach? While the uses of 3D models depend on modeling goals [5], such models do serve research purposes, particularly when we (1) take advantage of $3 \mathrm{D}$ modeling software that manages georeferenced data and permits interchangeable architectural components to increase locational precision, flexibility, and transparency of models, (2) think of 3D models not as standalone end-products but as part of a dynamic landscape, and (3) shift focus to the modeling process where as we move from mounds to maps to models, we acquire new knowledge about data collection, documentation, and interpretation than can lead to new archaeological questions and methodologies.

\section{CASE STUDY: COPAN, HONDURAS}

Ancient Maya society endured for over 2000 years (ca. 600BC-AD1521) across large parts of Mexico and Central America, and is well-known for architectural, astronomical, epigraphic, and calendric achievements. The Maya region comprised several semi-autonomous polities. One of the most influential was Copan (fig. 1).

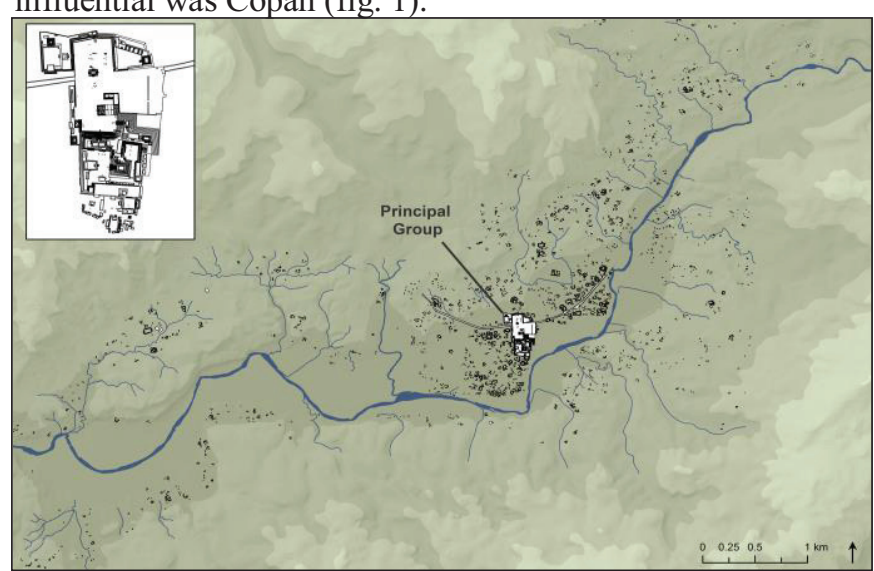

Fig. 1. Map of ancient city of Copan. Inset: Principal Group 
Today, Copan is an UNESCO World Heritage site located in western Honduras, but from the 5th to 9th centuries it was an important cultural and commercial center on the southeastern periphery of the Maya world. Early investigations focused on the city's main-civic ceremonial group - the Principal Group; however, from 1978-1980, the Proyecto Arqueológico Copán (PAC I) surveyed and instrument-mapped $24 \mathrm{~km}^{2}$ surrounding the Principal Group.

\section{METHODS}

\section{A. Phase I: From Mounds to Maps}

Producing maps from unexcavated mounds is a fuzzy process requiring mapmakers to interpolate what they "see" on the ground, and "reduce topographic relief to orderly lines" [6]. A range of techniques (influenced by what, where, when, why, who, and how) exist for mapping unexcavated mounds. In the Maya region such mapping typically requires archaeologists to make decisions about what lies beneath vegetation-covered mounds. Mapping decisions follow a set of conventions derived from using prismatic representations (known as the Maler method) (fig. 2). A major drawback to this technique is that buildings appear to have constant slope of forty-five degrees thus permitting markedly different cross sections, and impacting subsequent architectural modeling.

Using the prism technique, PAC I archaeologists at Copan mapped all visible mounds for a $24 \mathrm{~km}^{2}$ area and recorded any visible construction materials (e.g. worked vs. unworked stones, green tuff vs. limestone), sculpture, and surface artifacts. Contour lines ( $2 \mathrm{~m}$ for valley floor and foothills and $10 \mathrm{~m}$ for pine-covered mountains) and hydrological features were drawn from 1:4000 maps produced from stereoscopic aerial photographs. The result is a set of twenty-four maps (scale 1:2000) with hydrological features, contour lines, and almost 600 sites classified using the Harvard Site Typology [7] - a classification based primarily on architectural criteria and equated to socioeconomic status (Table 1) [8].

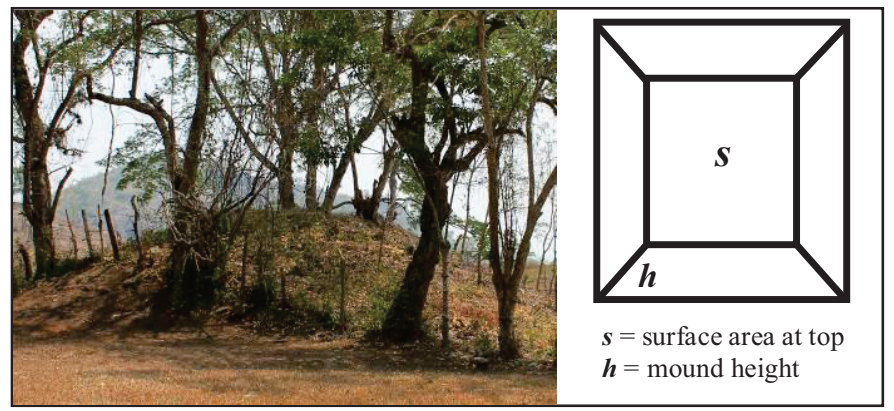

Fig. 2. Mound of unexcavated architecture, Copan, Honduras (left); Prism (Maler) technique for mapping mounds (right)

TABLE 1. HARVARD SITE TYPOLOGY

\begin{tabular}{|c|c|c|c|}
\hline $\begin{array}{c}\text { Site } \\
\text { Type }\end{array}$ & $\begin{array}{c}\text { No. of } \\
\text { Mounds }\end{array}$ & $\begin{array}{c}\text { Mound } \\
\text { Height (max) }\end{array}$ & Construction Materials \\
\hline $\mathbf{1}$ & $3-5$ & $0.25-1.25 \mathrm{~m}$ & $\begin{array}{c}\text { small/medium-sized earth fill; } \\
\text { undressed stones }\end{array}$ \\
\hline $\mathbf{2}$ & $6-8$ & $2.50-3.0 \mathrm{~m}$ & mostly undressed stones \\
\hline $\mathbf{3}$ & $6-8$ & $4.75 \mathrm{~m}$ & mostly undressed stones \\
\hline $\mathbf{4}$ & $\begin{array}{c}\text { multiple } \\
\text { plazas }\end{array}$ & $10 \mathrm{~m}$ & $\begin{array}{c}\text { large rough and dressed } \\
\text { stones; often have vault stones }\end{array}$ \\
\hline
\end{tabular}

For the case study, I scanned, georeferenced (UTM 16N), digitized and attributed three layers (contours, hydrology, and structures) from these maps using ESRI's ArcGIS 9.2. I digitized layers as lines, subsequently converting contours into a Digital Terrain Model (DTM), and structures into a polygon shapefile. (These data were originally created for GIS accessibility and visibility analyses [9].)

To attribute heights for unexcavated structures, I gathered data on Copan's excavated structures and ethnographic examples of modern Maya houses including information on how architectural construction affects heights $[9,10]$. I identified five variables that I could use, given the data constraints, to reconstruct structure heights: (1) platform height, (2) wall height, (3) roof pitch (angle), (4) wall thickness, and (5) structure width. (For a detailed description on how these variables and corresponding values were determined see Richards-Rissetto 2010:181-185.)

Next, using the Harvard Typology, which assigns construction materials and building form, I implemented a trigonometric function to calculate heights based on site type. Mound heights were not used because of structural collapse, as well as possible removal and reuse of architectural materials.

The general equation (Eq. 1) to calculate structure height is

$$
h=p+b+y
$$

where $p$ (platform height), $b$ (wall height) and $w$ (wall thickness) are constants based on site type (see Table 2) and $y=[(\mathrm{x}-\mathrm{w}) * \tan \theta]$. To solve for $\boldsymbol{y}$ (roof height), it is necessary to know $\theta$ (angle of roof pitch) - another constant based on site type - and $\boldsymbol{x}$ or one-half of structure width (fig. 3). To calculate $\boldsymbol{x}$, I used the ArcGIS 'Field Calculator' to multiply structure width by 0.5 for $\sim 3420$ mapped structures.

TABLE 2. VARIABLES AFFECTING STRUCTURE HEIGHTS

\begin{tabular}{|c|c|c|c|c|}
\hline $\begin{array}{c}\text { Site } \\
\text { Type }\end{array}$ & $\begin{array}{c}\text { Platform } \\
\text { Height }(\mathbf{m})\end{array}$ & $\begin{array}{c}\text { Wall Height } \\
(\mathbf{m})\end{array}$ & $\begin{array}{c}\text { Roof Pitch } \\
(\boldsymbol{\Theta})\end{array}$ & $\begin{array}{c}\text { Wall } \\
\text { Thickness }\end{array}$ \\
\hline $\mathbf{1}$ & 0.20 & 2.0 & $45^{\circ}$ & $\mathrm{N} / \mathrm{A}^{\mathrm{a}}$ \\
\hline $\mathbf{2}$ & 0.54 & 2.0 & $45^{\circ}$ & $\mathrm{N} / \mathrm{A}^{\mathrm{a}}$ \\
\hline $\mathbf{3}$ & 0.97 & 2.0 & $45^{\circ}$ & $\mathrm{N} / \mathrm{A}^{\mathrm{a}}$ \\
\hline $\mathbf{4}$ & 1.15 & 2.5 & $60^{\circ}$ & 1.0 \\
\hline \multicolumn{7}{|c}{${ }^{\mathrm{a}}$ Not applicable because thatch roofs do not require weight-bearing walls. }
\end{tabular}

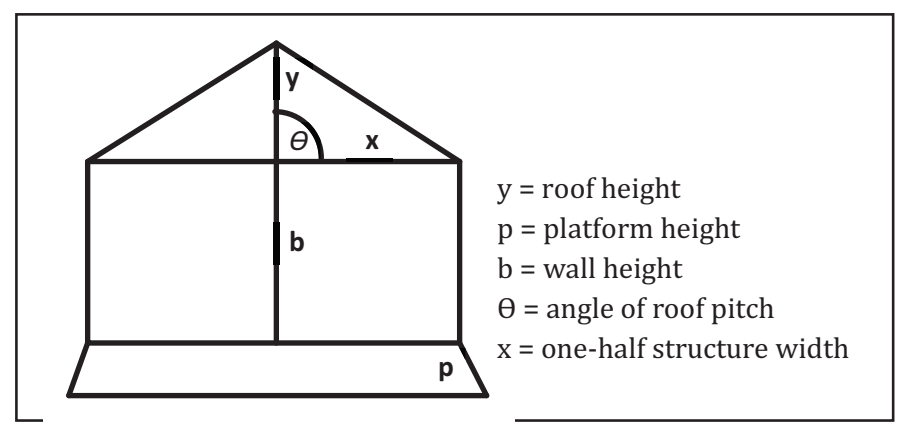

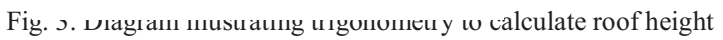

To calculate estimates for structure heights based on site type, equation 1 was adapted to four equations (Equations 2-5) that I implemented using the ArcGIS 'Field Calculator'. 
Type 1 Sites

$h=0.20+2.0+\left(\boldsymbol{x} * \tan 45^{\circ}\right)$

Type 2 Sites

$h=0.54+2.0+\left(\boldsymbol{x} * \tan 45^{\circ}\right)$

Type 3 Sites

$h=0.97+2.0+\left(\boldsymbol{x} * \tan 45^{\circ}\right)$

Type 4 Sites

$$
\left.h=1.15+2.5+\left[(x-1.0) * \tan 60^{\circ}\right)\right]
$$

The heights for unexcavated structures were stored in the attribute table of the 'structures' shapefile. (Because the original objective was to perform viewshed analysis between site types, platform height was included in the equation. The platform heights had to be subtracted for the $3 \mathrm{D}$ modeling using the 'Field Calculator'.) The final steps to prepare the GIS data for export to SketchUp (software to create 3D models) was to covert the shapefile from a line to polygon format and convert the DTM to a Triangulated Irregular Network (TIN).

\section{B. Phase II: From Maps to Models}

To generate 3D architectural models from the GIS footprints, I selected Trimble SketchUp (previously Google SketchUp) because it offers several advantages:

- Geo-referenced data can be imported

- Building templates can be created for faster modeling

- Architectural elements (e.g. stairs, platforms, roofs) can be organized as interchangeable components

- Architecture can be modeled on a landscape

- Models can be exported to several formats

The original process to export a TIN (terrain) and the georeferenced building footprints used the ArcGIS plugin for SketchUp and ArcGIS 9.3. The process in ArcGIS 10 is less straightforward. It requires using the 'Layer to 3D Feature Class' tool to convert the TIN or shapefile to multipatch (Esri's native $3 \mathrm{D}$ feature type), and then employ the 'Multipatch to collada' tool to convert the multipatch to a collada file (interchange file format for interactive 3D applications) that can be imported into SketchUp.

Once the TIN and GIS footprints are in SketchUp, it is not reasonable to simply extrude building footprints because the:

- $\quad$ prism (mapping) technique constrains platform angles to forty-five degrees,

- 3D models are extruded blocks,

- $\quad$ pitched roofs are not visualized, and

- buildings lack doorways making interior spaces inaccessible.

However, it is time-consuming to create nearly 3500 architectural models, one for each structure. (To date, about 800 models have been created.) To streamline the process, I created four building templates with sub-types using criteria from the Harvard Site Typology and excavations (fig. 4). (I added sub-types because (a) isolated mounds were modeled as ancillary structures and (b) excavations indicate that structures at type 2 urban sites were often plastered and had higher platforms than those at rural sites.) Construction materials range from pole and thatch for ancillary structures, to mudcolored adobe and thatch roofs for type 1 and 2 structures, to plastered ashlar masonry with thatch roofs for type 3 structures, to plastered ashlar masonry with corbel-vaulted roofs for type 4 structures. Textures were generated for adobe and stone construction from field photos, and plaster and paint from samples at Copan.

After the templates were created, they were placed on color-coded (according to site type) footprints. The final step was to scale the models along the $\mathrm{x}$ - and $\mathrm{y}$-axes according to the building footprints and then in the z-axis to adjust superstructure height based on GIS calculations. To properly scale structures requires that architectural features (i.e. stairs, platforms, superstructure walls, and roofs) be organized as components. If a model is not organized into components, it is scaled as a single object. Universal scaling is a problem, for example, when we need to preserve original platform heights but increase superstructure heights.

Of course, these templates are simplifications and do not account for formal variations, particularly in regard to interior layout; however, they offer a starting point (based on archaeological data) to efficiently model architecture across a vast landscape. It is also important to note that decisions were sometimes made to modify the templates to accommodate footprints; for example, I typically added one to two doors to long rectilinear structures (typical of such Maya structures) located at type 4 sites. In the modeling process, archaeologists come to better understand their data; inconsistencies become evident or variation can be revealed [11]. The process of translating maps to models can be streamlined, but it is not straightforward. However, rather than a deterrent, the anomalies and problems encountered should be seen as a way to make new observations about our data and interpretations.

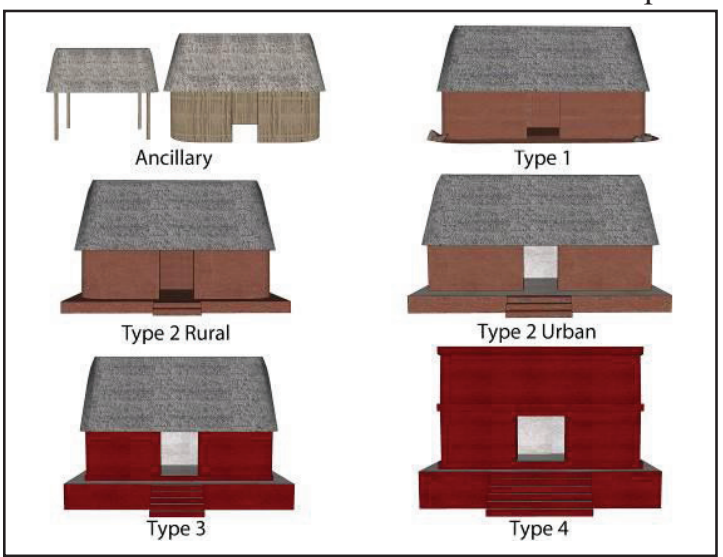

Fig. 4. Structure templates modeled in SketchUp

\section{CONCLUSIONS \& FUTURE DIRECTION}

This paper offers a GIS approach to create 3D architectural models generated from maps of unexcavated mounds. Because building footprints must be interpolated from mounds, there will always be uncertainty. While we cannot investigate the nuances or take precise measurements of individual buildings, we can create useful 3D models by generating them from georeferenced footprints and basing reconstructions on archaeological evidence (e.g. Harvard Site Typology). 
Using GIS, we can calculate structure heights from footprints and other archaeological data, and then export georeferenced footprints to SketchUp to create 3D architectural models (based on templates) to populate a vast landscape. This landscape context enables us to more intuitively interact with archaeological data and increases our awareness of spatial relationships between archaeological features and the landscape [12].

For example, we know from ancient Maya hieroglyphs that "seeing" afforded high status and sight had an authorizing gaze [13]. Such ideologies are embedded in ancient Maya landscapes as lines-of-sight between city temples and outlying stelae [14] or territorial viewsheds marking boundaries between ancient cities [15]. Moving from 2D maps to 2.5D viewsheds to $3 \mathrm{D}$ architectural models adds a new perspective to visibility studies, for instance, allowing us to "walk" though landscapes exploring how lines-of-sight or fields-of-view may have influenced how people moved about and interacted with each other and their landscapes [16].

Of key import is to think of these models not as fixed endproducts but as objects with interchangeable components that are part of a dynamic landscape, for example, where we can turn on and off temporal layers to visualize growth and development within a landscape. Moreover, architectural components can be interchanged to explore data, test interpretations, and develop research questions.

Future work will compare the GIS approach described in this paper to procedural modeling in regard to time-efficiency and modeling flexibility. Given the "standardized" vocabulary of Maya architecture, the ability to develop architectural libraries and apply rules could further automate the process and allow for easier interchange of components.

In sum, the models are multi-purpose-serving education, public outreach, and research. In moving from 2D maps to a 3D landscape, archaeologists, students, and the public acquire a sense of space and place as they investigate single structures and architectural complexes from multiple angles and then zoom out to analyze how architecture is situated in relation to other archaeological and topographic features in the landscape (fig. 5). Finally, the modeling process itself - as we move from mounds to maps to models-leads to questions urging us to rethink our data, methods, and our interpretations.

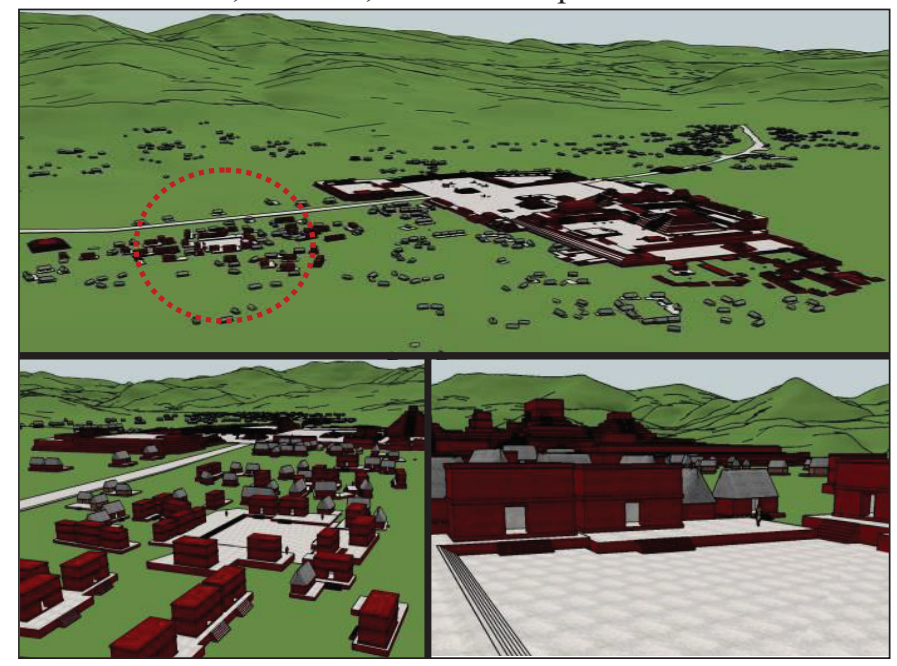

Fig.5. Illustrating interactivity of 3D models in landscape context

\section{ACKNOWLEDGMENT}

I sincerely thank the HUMlab, Umea University, Sweden and the 3D Optical Metrology Unit, Bruno Kessler Foundation for their support. I am grateful to the Instituto Hondureño de Antropología e Historia for its permission and support. This material is based on work supported by the National Science Foundation under Grant No. 1064648.

\section{REFERENCES}

[1] G. Wiley, Prehistoric settlement patterns in the Viru Valley, Peru. Bureau of American Ethnology Bulletin 155. Smithsonian Institution, Washington, DC. 1953.

[2] R. Wilk and W. Rathje, "Household Archaeology," American Behavioral Scientist, 25(6), pp. 617-639, 1982.

[3] D. Comer and M. Harrower, Mapping archaeological landscapes from space, Springer Briefs in Archaeology, pp. 85-95, 2013.

[4] F. Remondino et al., Multi-Sensor 3D documentation of the Maya site of Copan. Proceedings of 22nd CIPA Symposium, October 11-15, Kyoto, Japan, Commission, V, WGV/4, 2009.

[5] J. Kantner, "Realism vs. reality: creating virtual reconstructions of prehistoric architecture," in Virtual reality in Archaeology, J.A. Barcelo, M. Forte, and D.H. Sanders, Eds. Oxford: Archeopress, pp. 47-56 2000.

[6] S. Hutson, "Unavoidable imperfections," in Past presented: archaeological illustration and the ancient Americas, J. Pillsbury, Ed. Washington, D.C.: Dumbarton Oaks Research Library and Collection, pp. 283-316, 2012.

[7] G. Wiley and R. Leventhal, Prehistoric Settlement at Copan, in Maya Archaeology and Ethnohistory, N. Hammond and G. willey Eds. Austin: University of Texas Press, pp. 75-102, 1979.

[8] W. Fash and K. Long, Mapa arqueologico del Valle de Copán. Introducción a la arqueología de Copán, Honduras. Proyecto Arqueologico Copán, Secretaria de Estado en el Despacho de Cultura y Turismo, Tegucigalpa, D.C., 1983.

[9] H. Richards-Rissetto, Exploring social interaction at the ancient Maya city of Copán, Honduras: a multi-scalar Geographic Information Systems (GIS) analysis of access and visibility. Ph.D. Dissertation, University of New Mexico, 2010.

[10] R. Wauchope, Modern Maya houses: a study of their archaeological significance. Carnegie Institution of Washington, Washington, D.C., 1938.

[11] Hermon, S., 2008, "Reasoning in 3D: a critical appraisal of therRole of $3 \mathrm{D}$ modelling and virtual reconstructions in archaeology," in B. Frischer and A. Dakouri-Hild (eds.), Beyond illustration: 2D and 3D technologies as tools for discovery in archaeology, Archaeopress, Oxford, pp. 36-45.

[12] B. Frischer and A. Dakouri-Hild, Beyond illustration: 2d and 3d digital technologies as tools for discovery in archaeology. Oxford: Archeopress, 2008.

[13] S. Houston, D. Stuart, and K. Taube, The memory of bones: body, being, and experience among the Classic Maya. Austin: University of Texas, 2006.

[14] N. Hammond and G. Tourtellot, "Shifting axes: spatial expressions of power at La Milpa," unpublished.

[15] J. Doyle, T. Garrison, and S. Houston. Watchful realms: integrating GIS analysis and political history in southern Maya lowlands. Antiquity 68: pp. 792-807, 2012.

[16] M. Llobera, Building past landscape perception with GIS: understanding topographic prominence. Journal of Archaeological Science 28, pp. 1005-1014, 2001. 